\title{
ANALYTICAL RESULTS OF THE STABILITY OF SOME LIMESTONE ISLANDS IN HA LONG BAY, QUANG NINH PROVINCE OF VIETNAM, A WORLD NATURAL HERITAGE
}

\author{
Phi Truong Thanh
}

\author{
Hanoi University of Natural Resources and Environment, Vietnam \\ Corresponding author: thanhgislab@gmail.com
}

Received Date: 04 September 2019, Accepted Date: 17 November 2019, Published Date: 26 December 2019

\section{ABSTRACT}

The analytical results of the failure types of six limestone islands in the Ha Long bay of Vietnam have been identified. The calculated results of safety factor for 03 plane failure blocks lie within 0.9 and 2, have high potential failure. The analytical results have been also simulated these islands in three-dimensional space and have been also analyzed their potential failure on the fracture surfaces. The results obtained in this paper have important significance for planning and development of the Ha Long bay area, as World Natural Heritage, Quang Ninh province of Vietnam.
\end{abstract}

Keywords: Ha Long bay, Limestone, Plane failure, Stability, Vietnam.

\section{INTRODUCTION}

The Ha Long bay belongs to the west coast of Tonkin Gulf, Northeast area of Vietnam, including the islands of Ha Long city and Cam Pha city of Quang Ninh province (Maps 1, 2). The Ha Long bay is limited within the area of about $1,553 \mathrm{~km}^{2}$, including 1969 islands. Most of them are limestone islands of Carbon-Pecmi age of Bac Son formation. Based on the aesthetic value of geology - geomorphology that given by nature, the Ha Long bay has become a famous spot of Vietnam with two times recognized as a World Natural Heritage by UNESCO in the years 1994 and 2000. Therefore, this area has also become a place have a great potential of tourism with the million people visited the bay each year (Long, 2012). 
Analytical results of the stability of some limestone

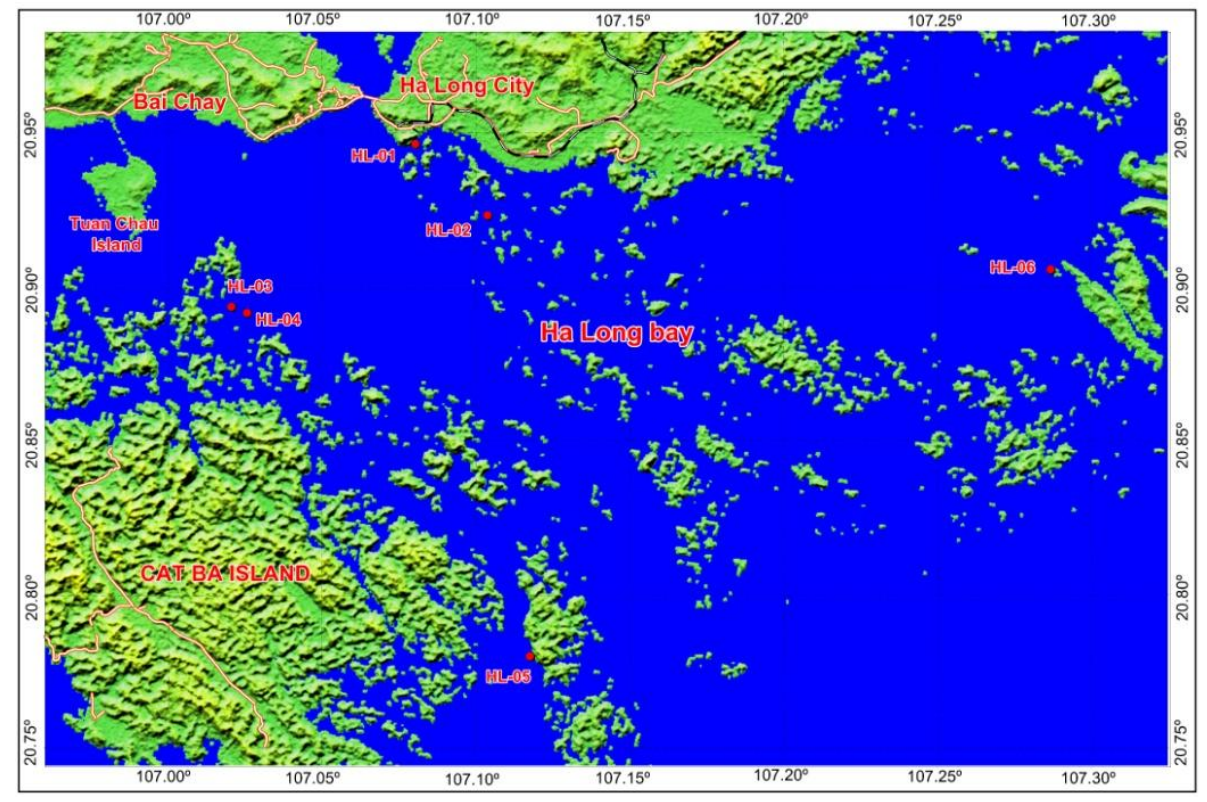

Map (1): Location map of survey sites in the Ha Long bay.

However, in the year 2016, due to the impact of failure has led to the disappearance of the head of the Thien Nga island (Pl. 1b), affecting the sustainable development of the heritage area.
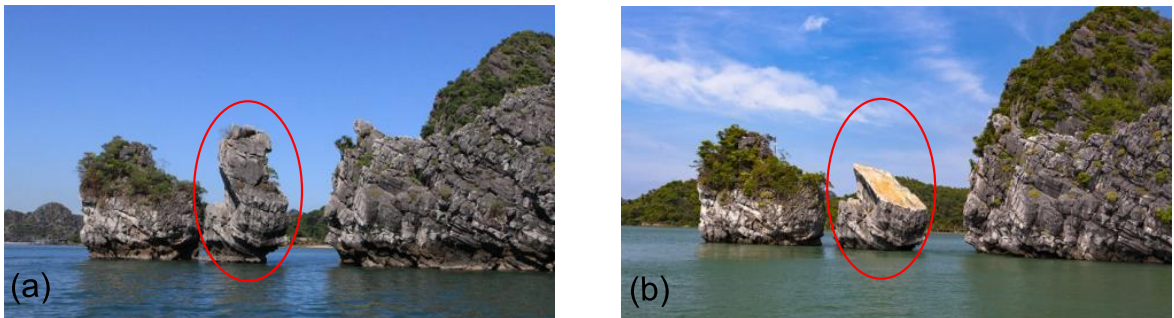

Plate (1): The head of Thien Nga island (HL-06) was cut due to the plane failure (a and b).

The studies on Ha Long bay have been carried out for many years of the last century and focused mainly on the landscape, geology and geomorphology (Lam and Boyd, 2002; Thanh and Tony, 2001; Thanh et al., 2004; Thanh, 2008; Thanh, 2012) and the environment for tourism development (Anh, 2015). However, studies of landslide in this area have just only been carried out in recent years. Typically, a provincial-level scientific and technological research project with the topic: "Research on geological processes, modern geodynamics for observation of changes in caves and islands in Ha Long bay" was performed by Van (2012). The results of this study have clearly analyzed and assessed the possible risk of rock slide on limestone islands to support for planning, conservation and hazard mitigation. Recently, Thanh et al. (2017) has used the Hoek and Bray (2004)'s application to identify the failure types that can occur on limestone blocks of Carbon-Pecmi age in the north area of Ha Long bay and has been indicated that this place can mainly occur plane failure. 


\section{Phi Truong Thanh}

In order to enrich the database, the author collects field data of failure on the limestone islands, was collected and analyses for the potential failure types of the limestone islands which are the symbol of Ha Long bay and simulate them in 3D space to support for the conservation and development.

\section{Materials}

\section{MATERIALS AND METHODS}

The field survey is conducted by measuring the fracture orientation and describing the characteristics of fault, fracture and size of failure block, the image of each survey location of failure block is also recorded as a basis for drawing the failure blocks in detail.

The coordinates of survey locations and information on the fracture at each survey location are summarized in Table (1).

Table (1): The information of survey locations.

\begin{tabular}{|c|c|c|c|c|}
\hline $\begin{array}{l}\text { Survey } \\
\text { location } \\
\text { index }\end{array}$ & $\begin{array}{c}\text { Longitude } \\
\text { (degree) }\end{array}$ & $\begin{array}{l}\text { Latitude } \\
\text { (degree) }\end{array}$ & $\begin{array}{c}\text { Fracture } \\
\text { orientation }\end{array}$ & Description \\
\hline HL-01 & $107^{0} 04^{\prime} 50.0^{\prime \prime}$ & $20^{0} 56^{\prime} 46.3^{\prime \prime}$ & $020^{0} / 60^{0}$ & Bai Tho island \\
\hline HL-02 & $107^{0} 06^{\prime} 14.6^{\prime \prime}$ & $20^{0} 55^{\prime} 22.7^{\prime \prime}$ & $\begin{array}{l}170^{\circ} / 50^{\circ} \\
250^{\circ} / 40^{\circ} \\
230^{\circ} / 70^{\circ}\end{array}$ & \\
\hline HL-03 & $107^{0} 01^{\prime} 14.5^{\prime \prime}$ & $20^{0} 53^{\prime} 35.6 \prime$ & $\begin{array}{l}200^{\circ} / 40^{0} \\
195^{\circ} / 60^{\circ} \\
085^{\circ} / 90^{\circ} \\
130^{\circ} / 70^{\circ}\end{array}$ & Dinh Huong island \\
\hline HL-04 & $107^{0} 01 ’ 33.0^{\prime \prime}$ & $20^{0} 53^{\prime} 28.5^{\prime \prime}$ & $\begin{array}{l}060^{0} / 30^{0} ; \\
185^{0} / 30^{0} ; \\
175^{0} / 45^{0} ; \\
056^{0} / 82^{0} ; \\
200^{0} / 45^{0}\end{array}$ & Ga Choi island \\
\hline HL-05 & $107^{\circ} 07^{\prime} 04.32^{\prime \prime}$ & $20^{\circ} 46^{\prime} 46.20^{\prime \prime}$ & $205^{\circ} / 40^{\circ}$ & But island \\
\hline HL-06 & $107^{\circ} 17^{\prime} 14.39^{\prime \prime}$ & $20^{\circ} 54^{\prime} 19.59^{\prime \prime}$ & $\begin{array}{l}230^{0} / 35^{0} \\
075^{0} / 70^{0} \\
235^{0} / 30^{0} \\
230^{\circ} / 40^{\circ}\end{array}$ & $\begin{array}{l}\text { Thien Nga } \\
\text { island }\end{array}$ \\
\hline
\end{tabular}

\section{Methods}

The method for failure analyses: wedge failure, toppling failure and circular failure is carried out according to Hoek and Bray (2004)'s application, based on the fracture orientation in three-dimensional space. The analytical results will be identified the types: plane failure, wedge failure, toppling failure and geometries of the rock slope failure as shown in the Diagrams $(1,2)$. 
Analytical results of the stability of some limestone
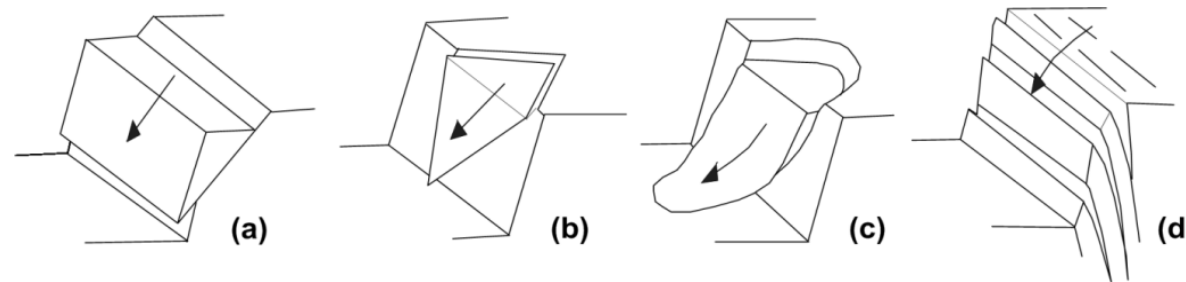

Diagram (1): Pattern of failure on the slope surface (Hoek and Bray, 2004); (a) Plane failure, the fracture orientation is sub-parallel to slope surface, (b) Wedge failure, which slide on the intersection of two fracture surfaces, (c) The circular failure in the weak rock, with the random fracture orientation, (d) Toppling failure occurs in hard rock that have the fracture surface which is inclined to slope surface.
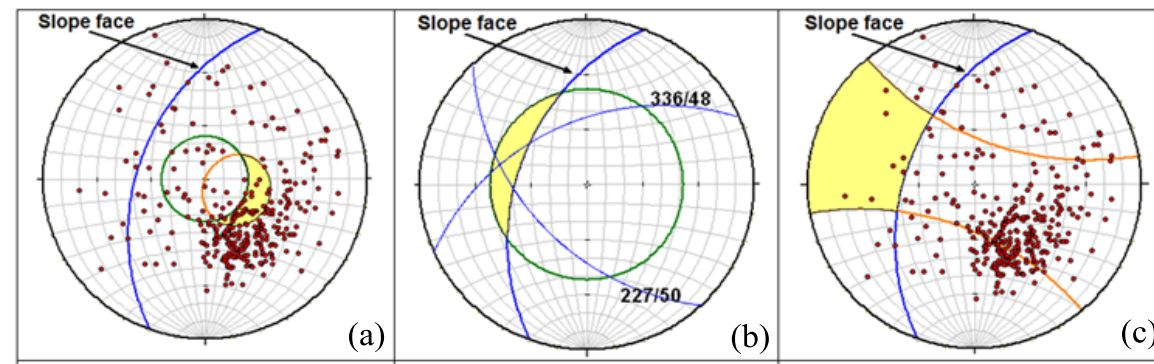

Diagram (2): (a) Plane failure, (b) wedge failure, (c) toppling failure (according to Hoek and Bray (2004)).

The Diagrams $(1,2)$ have been used by Thanh et al. (2018). To calculate the safety factor for each fracture surface, the Equation (1) is used. According to Hoek and Bray (2004), the safety factor FS is calculated following the parameters: $\mathrm{U}, \mathrm{V}$ and $\mathrm{W}$ from Equations 2-5 and from figures on the Diagrams (3). 
Phi Truong Thanh

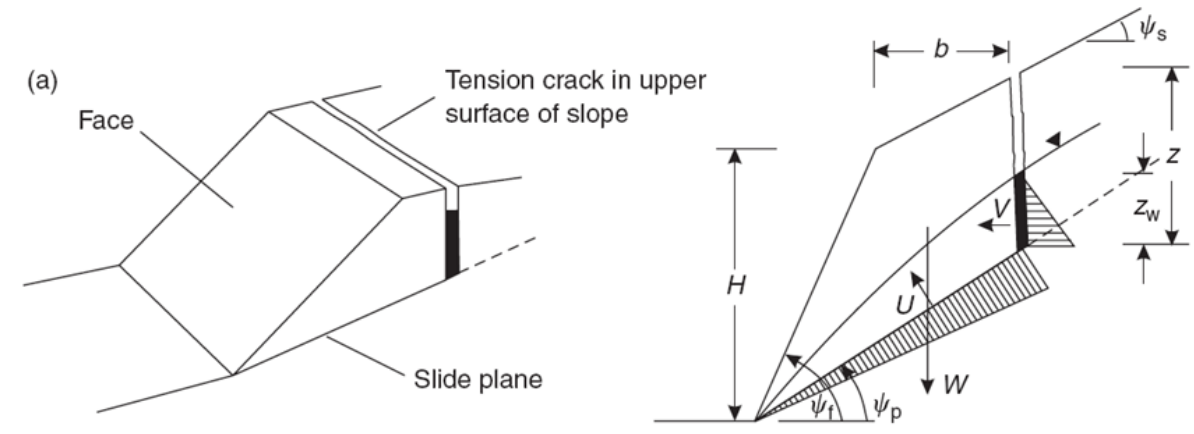

(b) Tension crack in face
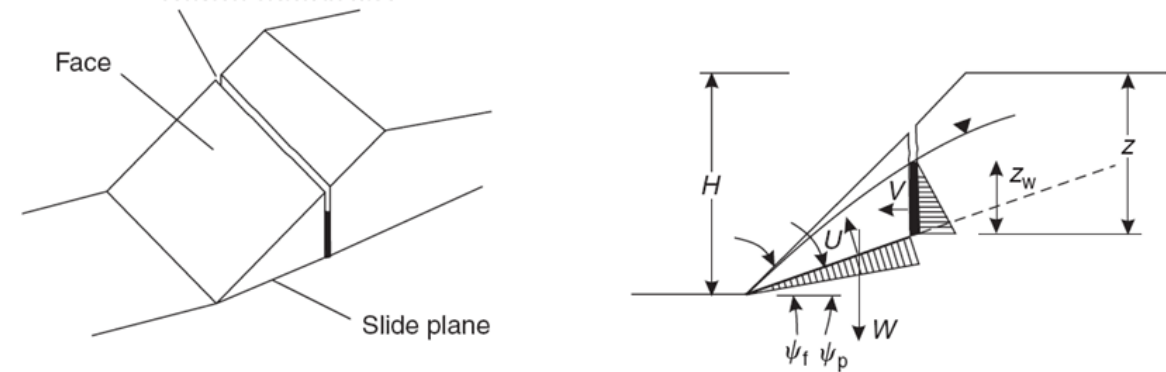

Diagram (3): Geometries of plane slope failure; (a) tension crack in the upper slope,

(b) tension crack in the face (Hoek and Bray, 2004).

$$
\mathrm{FS}=\frac{c A+\left(W \cos \psi_{p}-U-V \sin \psi_{p}\right) \tan \phi}{\mathrm{W} \sin \psi_{\mathrm{p}}+\mathrm{V} \cos \psi_{\mathrm{p}}}
$$

Where $\mathrm{c}$ is the cohesion and $\mathrm{A}$ is the area of the sliding plane.

$$
\mathrm{A}=\left(\mathrm{H}+\mathrm{b} \tan \psi_{s}-\mathrm{z}\right) \operatorname{cosec} \psi_{p}
$$

The slope height is $\mathrm{H}$, the tension crack depth is $z$ and it is located a distance behind the slope crest. The dip of the slope above the crest is $\psi_{\mathrm{s}}$. When the depth of the water in the tension crack is $z_{\mathrm{w}}$, the water forces acting on the sliding plane $\mathrm{U}$ and in the tension crack $\mathrm{V}$ are given by:

$$
\begin{aligned}
& \mathrm{U}=\frac{1}{2} \gamma_{w} z_{w}\left(H+b \tan \psi_{s}-z\right) \operatorname{cosec} \psi_{p} \\
& \mathrm{~V}=\frac{1}{2} \gamma_{w} z_{w}^{2}
\end{aligned}
$$

Where $\gamma_{\mathrm{w}}$ is the unit weight of water.

For the tension crack in the inclined upper slope surface (Pl.3a),

$$
\mathrm{W}=\frac{1}{2} \gamma_{r}\left[\left(1-\cot \psi_{f} \tan \psi_{p}\left(b H+\frac{1}{2} H^{2} \cot \psi_{f}\right) \frac{1}{2} b^{2}\left(\tan \psi_{s}-\tan \psi_{p}\right)\right]\right.
$$

And, for the tension crack in the slope face (Pl.3b). 
Analytical results of the stability of some limestone

$$
\mathrm{W}=\frac{1}{2} \gamma_{r} H^{2}\left[\left(1-\frac{z}{H}\right)^{2} \cos \psi_{p} x\left(\cos \psi_{p} \tan \psi_{f}-1\right)\right]
$$

Where $\gamma_{\mathrm{r}}$ is the unit weight of the rock.

Besides, the author also uses the softwares: Corel draw 12 and Photoshop CS3 to model limestone islands in 3D space.

\section{Identification of failure block}

\section{RESULTS}

Survey location HL-01 (Bai Tho island):

The survey location is ash-gray limestone block, this limestone block has many large fractures with orientation $020^{\circ} / 60^{\circ}$, parallel to each other and divided into layers with the thickness varies in the range of 3-8m (Pl.2a). The analytical results according to Hoek and Bray (2004)'s application have determined, it is possible to occur plane failure on the fracture orientation $020^{\circ} / 60^{\circ}$ and slope orientation $300^{\circ} / 75^{\circ}(\mathrm{Pl} .2 \mathrm{~b})$.

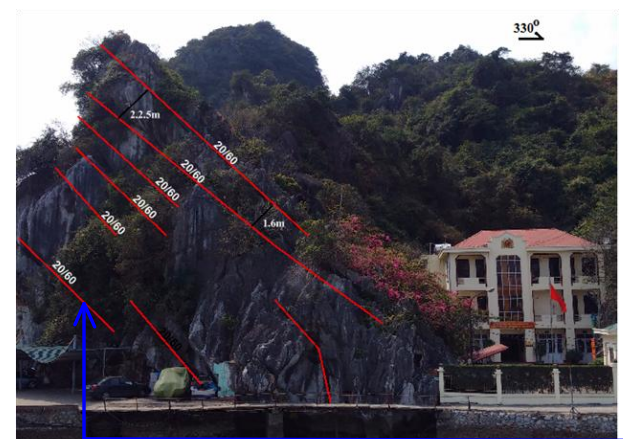

(a)

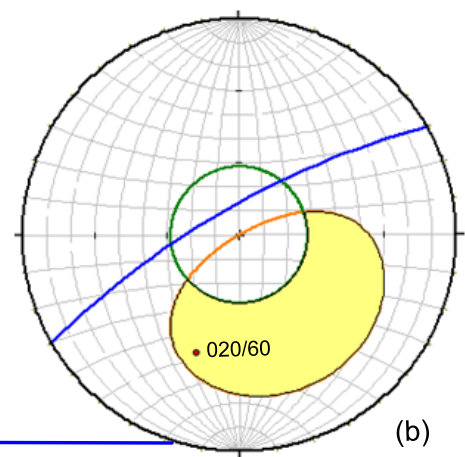

Plate (2): (a) Photo of survey location HL-01, (b) Plane failure can occur on the fracture orientation $020^{\circ} / 60^{\circ}$ and slope orientation $300^{\circ} / 75^{\circ}$.

The model of plane failure of the survey location HL-01 is plotted in the Figure (1).
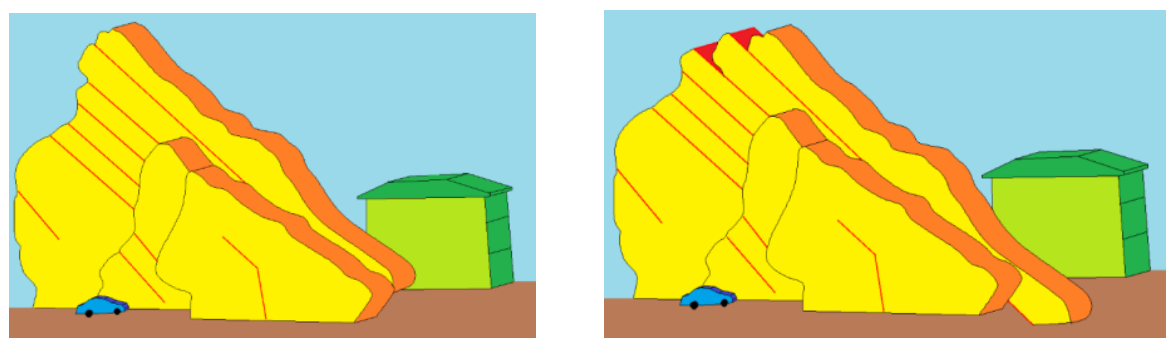

Figure (1): 3D model of limestone block and its potential failure at survey location HL-01.

Survey location HL-02:

The survey location is a limestone island. It has white-gray color and block structure. The fracture orientations are $170^{\circ} / 50^{\circ}, 250^{\circ} / 40^{\circ}, 060^{\circ} / 55^{\circ}, 230^{\circ} / 75^{\circ}(\mathrm{P} 1.3 \mathrm{a})$. The analytical results according to Hoek and Bray (2004)'s application have determined, it is possible to occur plane failure on the fracture orientation $250^{\circ} / 40^{\circ}$ and slope orientation $230^{\circ} / 85-90^{\circ}(\mathrm{Pl} .3 \mathrm{~b})$. 
Phi Truong Thanh

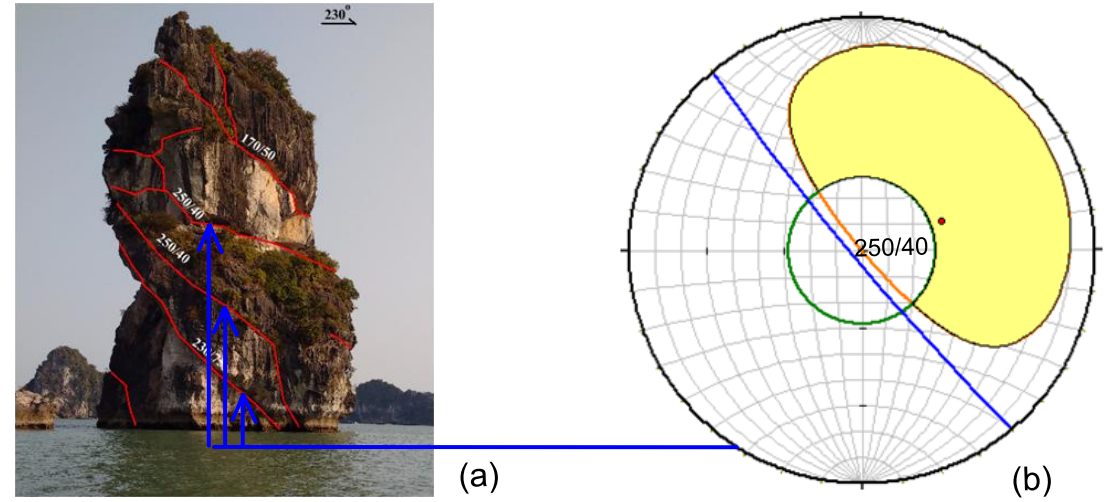

Plate (3): (a) Photo of survey location HL-02, (b) Plane failure can occur on the fracture orientation $250^{\circ} / 40^{\circ}$ and slope orientation of $230^{\circ} / 85-90^{\circ}$.

The model of plane failure of the survey location HL-02 is plotted in Figure (2).
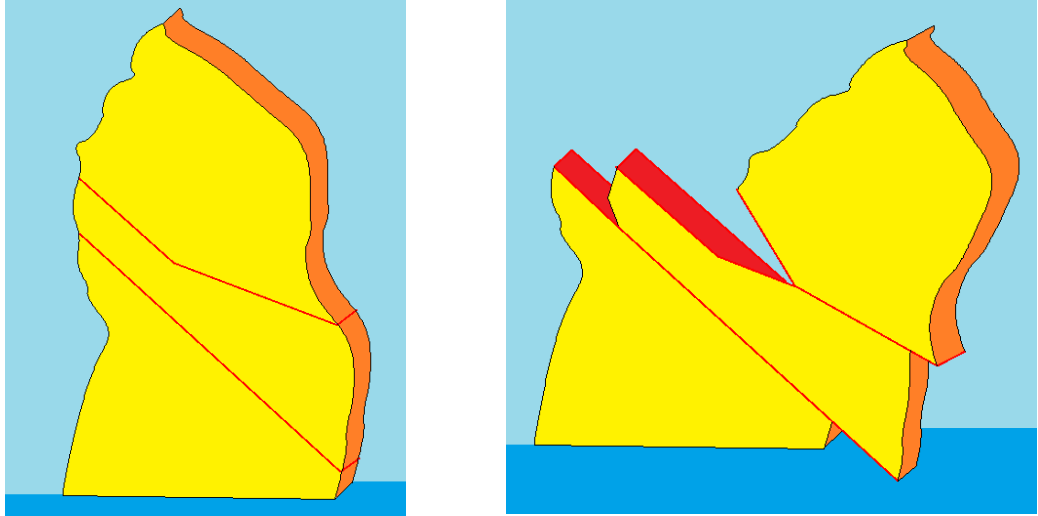

Figure (2): 3D model of limestone block and potential failure at survey location HL-02.

Survey location HL-03 (Dinh Huong Island):

Dinh Huong Island has a block structure, which is divided into layers by different fracture systems (Pl.4a). The analytical results according to Hoek and Bray (2004)'s application have determined, it is possible to occur plane failure on the fracture orientations: $195^{\circ} / 60^{\circ}, 200^{\circ} / 40^{\circ}$ and slope orientation $205^{\circ} / 85-90^{\circ}(\mathrm{Pl} .4 \mathrm{~b})$. 
Analytical results of the stability of some limestone

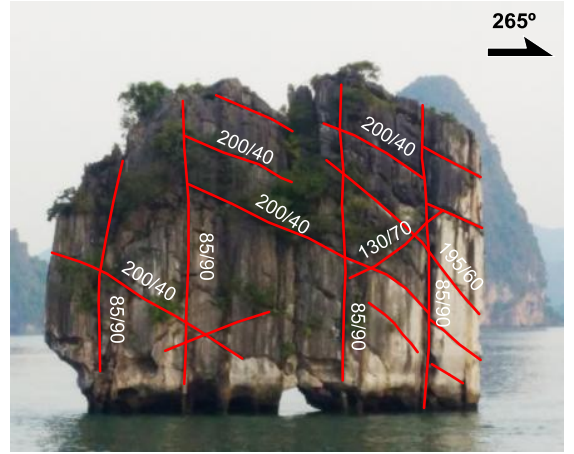

(a)

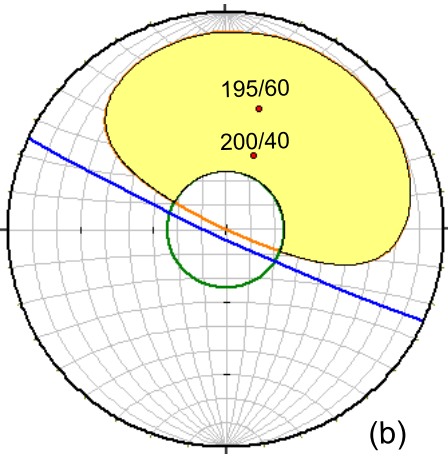

Plate (4): (a) Photo of survey location HL-03, (b) Plane failure can occur on the fracture orientations: $195^{\circ} / 60^{\circ}, 200^{\circ} / 40^{\circ}$ and slope orientation $205^{\circ} / 85-90^{\circ}$.

The model of plane failure of the survey location HL-03 is plotted in the Figure (3).
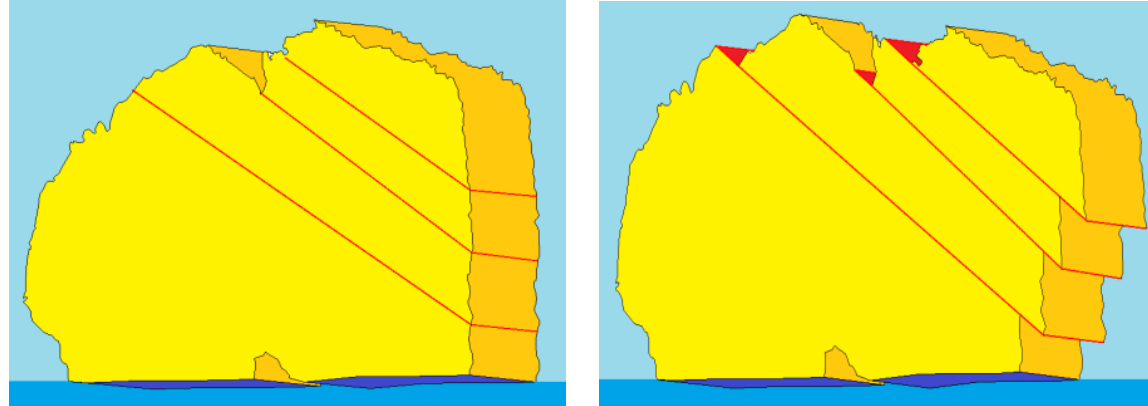

Figure (3): 3D model of limestone block and potential failure at survey location HL-03.

Survey location HL-04 (Ga Choi Island):

The Ga Choi Island is composed of limestone, thick layered of Bac Son formation (P1.5a). The fracture orientations: $175^{\circ} / 45^{\circ}, 185^{\circ} / 30^{\circ}$ and $200^{\circ} / 45^{\circ}$ can occur plane failure in the direction of slope $190^{\circ}$ and fracture orientations: $060^{\circ} / 50^{\circ}$ và $065^{\circ} / 82^{\circ}$ can occur plane failure on the slope orientation $060^{\circ} / 85-90^{\circ},(\mathrm{Pl} .5 \mathrm{~b})$.

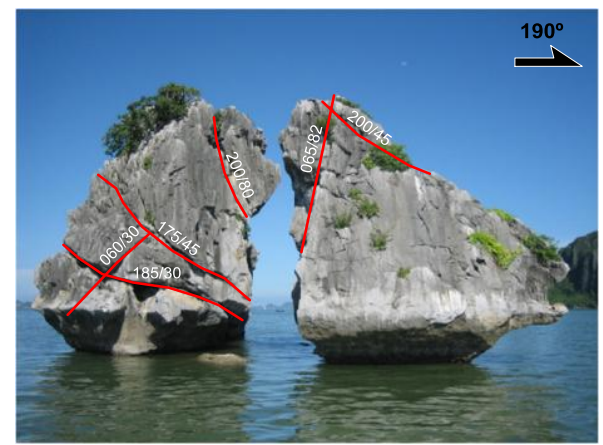

(a)

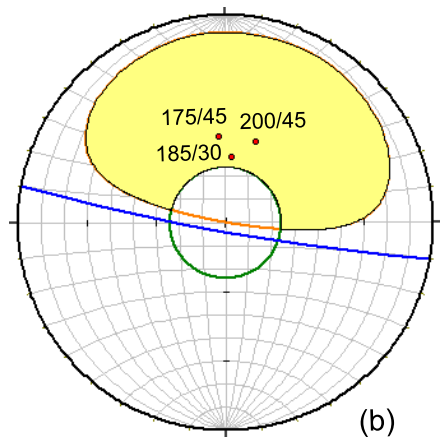

Plate (5): (a) Photo of survey location HL-04, (b) Plane failure can occur on the fracture orientations: $175^{\circ} / 45^{\circ}, 185^{\circ} / 30^{\circ}$ and $200^{\circ} / 45^{\circ}$ and slope orientation $190^{\circ} / 85-90^{\circ}$. 


\section{Phi Truong Thanh}

The model of plane failure of the survey location HL-04 is plotted in the Figure (4).
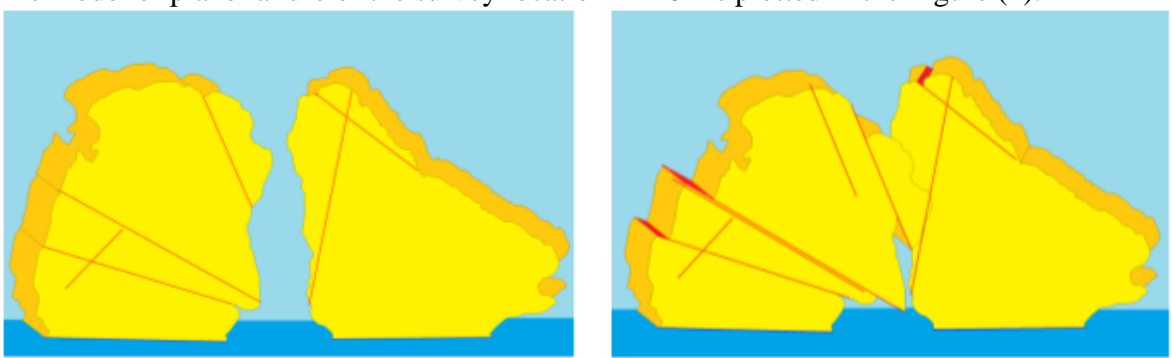

Figure (4): 3D model of limestone block and potential failure at survey location HL-04.

Survey location HL-05 (But Island):

The survey location is a small island, about $44.2 \mathrm{~m}$ high and has a pen-shaped cylinder (P1.6a). Tthe limestone is solid, block structure; the fracture develops in the NW - SE direction with sparse density. The analytical results according to Hoek and Bray (2004)'s application have determined, it is possible to occur plane failure on the fracture orientation $205^{\circ} / 40^{\circ}$ and slope orientation $200^{\circ} / 85-90^{\circ}$ (Pl. 6b).

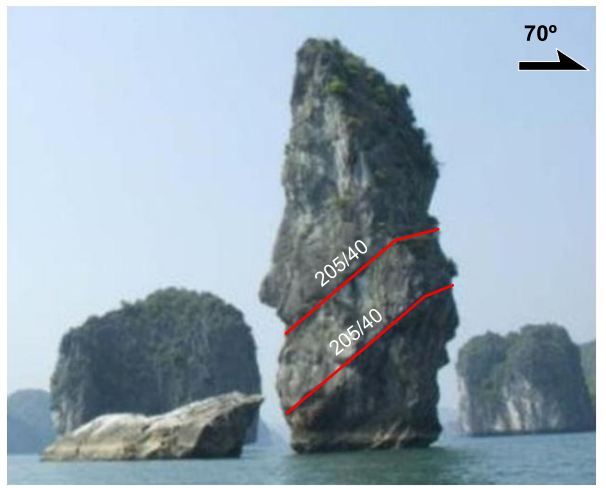

(a)

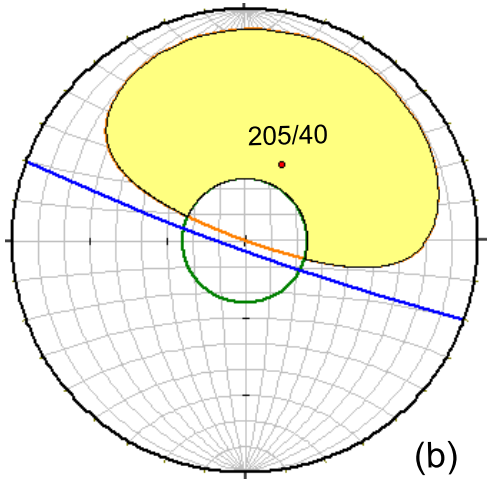

Plate (6): (a) Photo of survey location HL-05, (b) Plane failure can occur on the fracture orientation $205^{\circ} / 40^{\circ}$ and slope orientation $200^{\circ} / 85-90^{\circ}$.

The model of plane failure of the survey location HL-05 is plotted in the Figure (5).
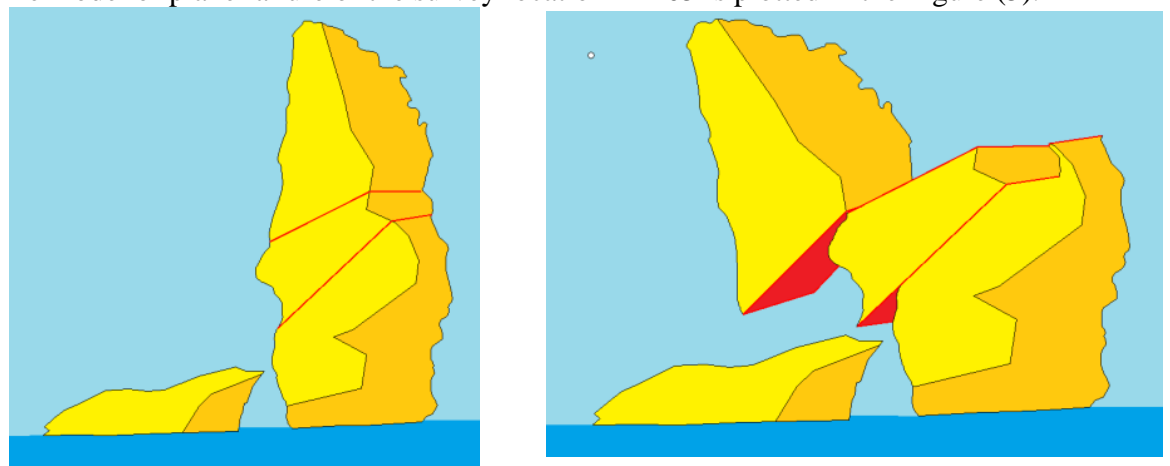

Figure (5): 3D model of limestone block and potential failure at survey location HL-05 
Analytical results of the stability of some limestone

Survey location HL-06 (Thien Nga Island):

The Thien Nga Island consists of two small blocks, composed of limestone with thin layers, rich silic, belonging to Cat $\mathrm{Ba}$ formation (Pls.7a, 8a). The analytical results according to Hoek and Bray (2004)'s application have determined, it is possible to occur plane failure on the fracture orientations: $230^{\circ} / 40^{\circ}$ and $075^{\circ} / 70^{\circ}$ and slope orientations: $230^{\circ} / 85-90^{\circ}$ and $070^{\circ} / 85$ $90^{\circ}$ (Pls. 7b, 8b).

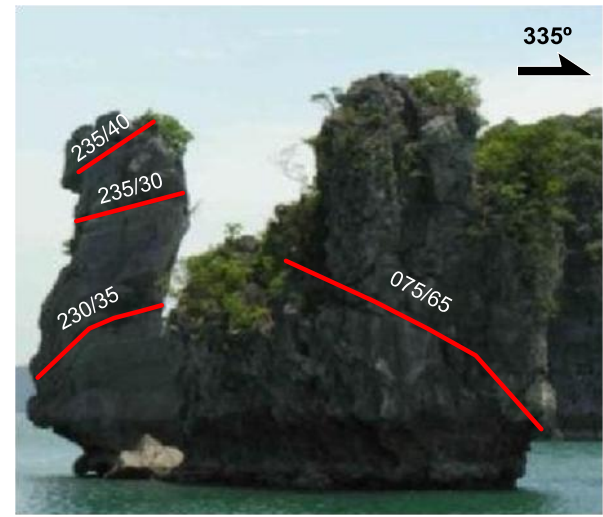

(a)

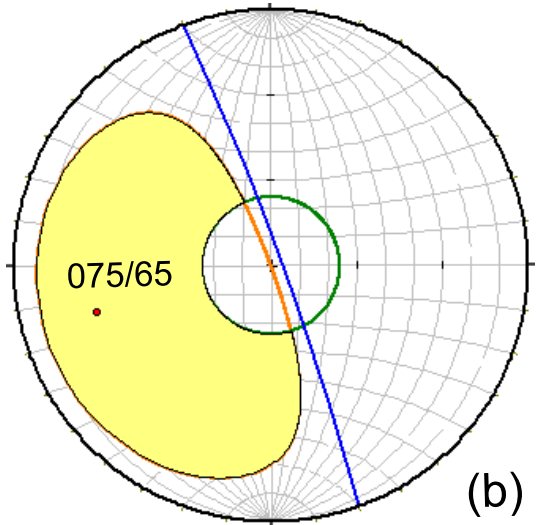

Plate (7): (a) Photo of survey location HL-06, (a) Plane failure can occur on the fracture orientation $075^{\circ} / 70^{\circ}$ and slope orientation $230^{\circ} / 85-90^{\circ}$.

The model of plane failure of the survey location HL-06 is plotted in the Figure (6).
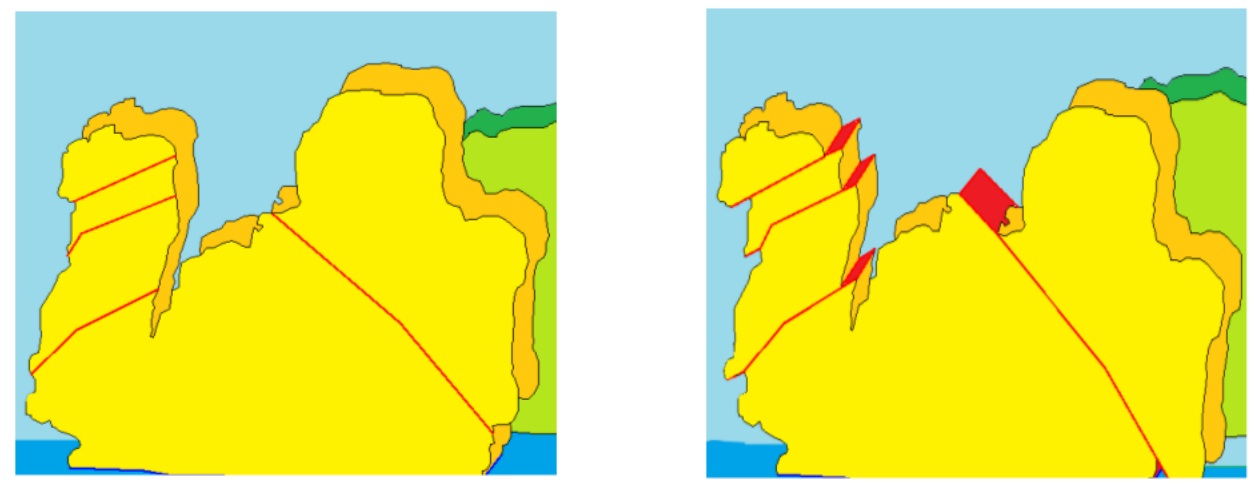

Figure (6): 3D model of limestone block and potential failure at survey location HL-06. 
Phi Truong Thanh

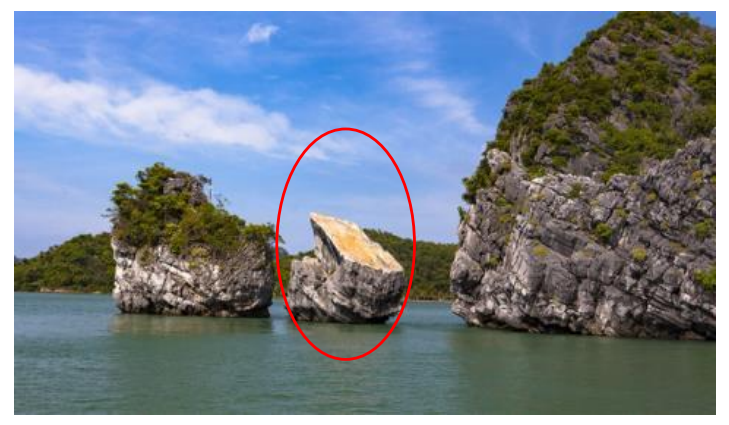

(a)

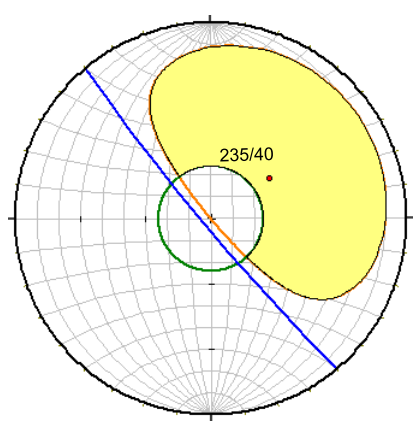

(b)

Plate (8): A head of Thien Nga Island (a) is cut by plane failure of fracture orientation $235^{\circ} / 40^{\circ}$ (b).

\section{Safety factor}

The safety factor calculation for some limestone islands which are the symbol of Ha Long bay are carried out following the formulas (1-5). The calculated results and their models are shown in detail in the Plates (9-11).

The first block of Dinh Huong Island at survey location HL-03:
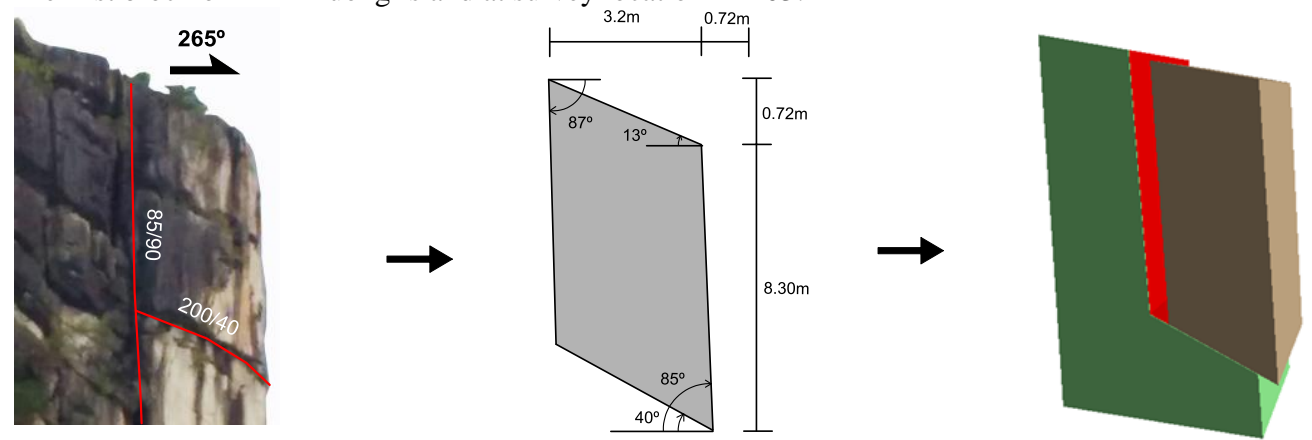

Plate (9): Model of plane failure block of the fracture orientation $200^{\circ} / 40^{0}$ of Dinh Huong Island at survey location HL-03 in the case of it has tension crack.

The calculated results of input parameters: Slope angle $=85$ degrees; Slope height $=8.3 \mathrm{~m}$; Unit weight $=2.67 \mathrm{t} / \mathrm{m}^{3} ;$ Failure plane $=40$ degrees; Tension crack $=87$ degrees; Upper face $=13$ degrees; Friction angle $=35$ degrees; Cohesion $=4.2 \mathrm{t} / \mathrm{m}^{2}$ have determined the safety factor to be 1.31 . 
The second block of Dinh Huong Island at survey location HL-03:
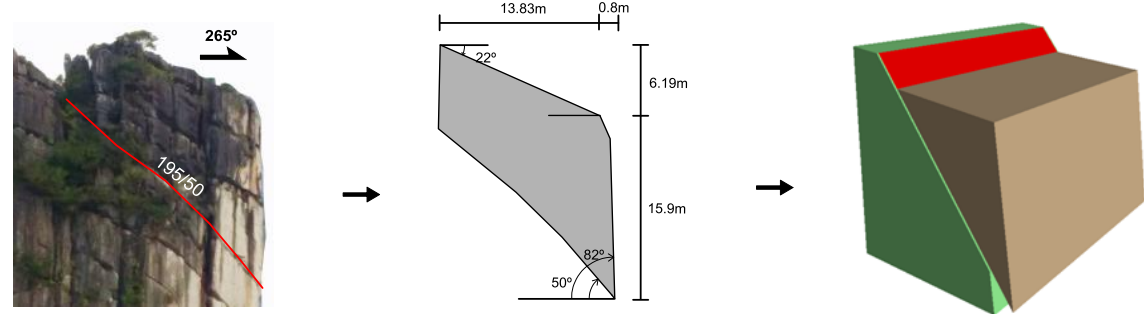

Plate (10): Model of plane failure block of the fracture orientation $195^{\circ} / 50^{\circ}$ of Dinh Huong Island at survey location HL-03 in the case of it has not tension crack.

The calculated results of input parameters: Slope angle $=82$ degrees; Slope height $=15.9 \mathrm{~m}$ Unit weight $=2.67 \mathrm{t} / \mathrm{m}^{3} ;$ Failure plane $=50$ degrees; Upper face $=22$ degrees; Friction angle $=35$ degrees; Cohesion $=4.2 \mathrm{t} / \mathrm{m}^{2}$ have determined the safety factor to be 0.91 .

The third block of Thien Nga (Swan) island at survey location HL-06:

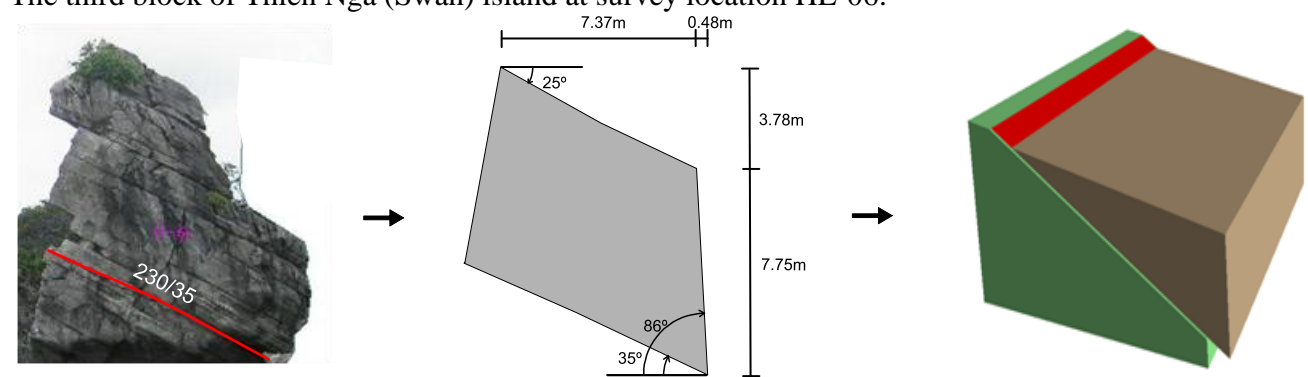

Plate (11): Model of plane failure block of the fracture orientation $230^{\circ} / 35^{\circ}$ of Thien Nga (Swan) Island.

The calculated results of input parameters: Slope angle $=86$ degrees; Slope height $=7.75 \mathrm{~m}$; Failure plane $=40$ degrees; Upper face $=25$ degrees; Friction angle $=35$ degrees; Cohesion $=$ $4.2 \mathrm{t} / \mathrm{m}^{2}$ have determined the safety factor to be 1.80 .

The obtained results from 03 models (Pls. 9-11) indicate that the safety factors of plane failure blocks of the limestone islands of Ha Long bay vary within 0.9 and 2, in the range of the high failure potential. These results have important significance for planning and conserving the Ha Long bay area, as a World Natural Heritage, at Quang Ninh province of Vietnam.

\section{DISCUSSION}

The Ha Long bay is located in the northeast part of Vietnam, dominated by two main tectonic forces due to the movement of the India-Australian plate to the north and the Pacific plate to the west, formed the compressive and extensive area (Phach et al., 1996). Some the other study results have suggested that the northeast region of Vietnam, including Ha Long bay occurred two major phases of tectonic activity in the Cenozoic period (Yem, 1991; Phach et al., 1996). The first phase was determined to be the compressive stress state in the direction 


\section{Phi Truong Thanh}

E-W, occurred from Eocene to late Miocene period and the second phase was determined to be the compressive stress state in the direction N-S, occurred during the Pliocene-Quaternary period (Chinh, 2002). The first tectonic activity phase has caused the left lateral strike-slip motion of the NW-SE fault system and the second phase has caused the right lateral strikeslip motion of this fault system. In particular, the Red River fault system and Cao Bang - Tien Yen fault zone are two large fault zones, clearly reflected the stress state of both phases (Map2).

The left lateral strike-slip motion of the Red River fault system was suggested that it was the results of the India-Eurasia plate collision (Map.2) (Tapponnier et al., 1986) and it occurred during within 30 to $5.5 \mathrm{Ma}$, corresponding to the Oligocene-Miocene period, from analytical results of the seismic data (Rangin et al., 1995). The other analytical result of seismic profiles in the north area of the Red River sedimentary basin also identified one phase of left lateral strike-slip motion which occurred about before $21 \mathrm{Ma}$ within the Lo River and Chay River fault zone, belong to the Red River fault system (Vu, 2003).

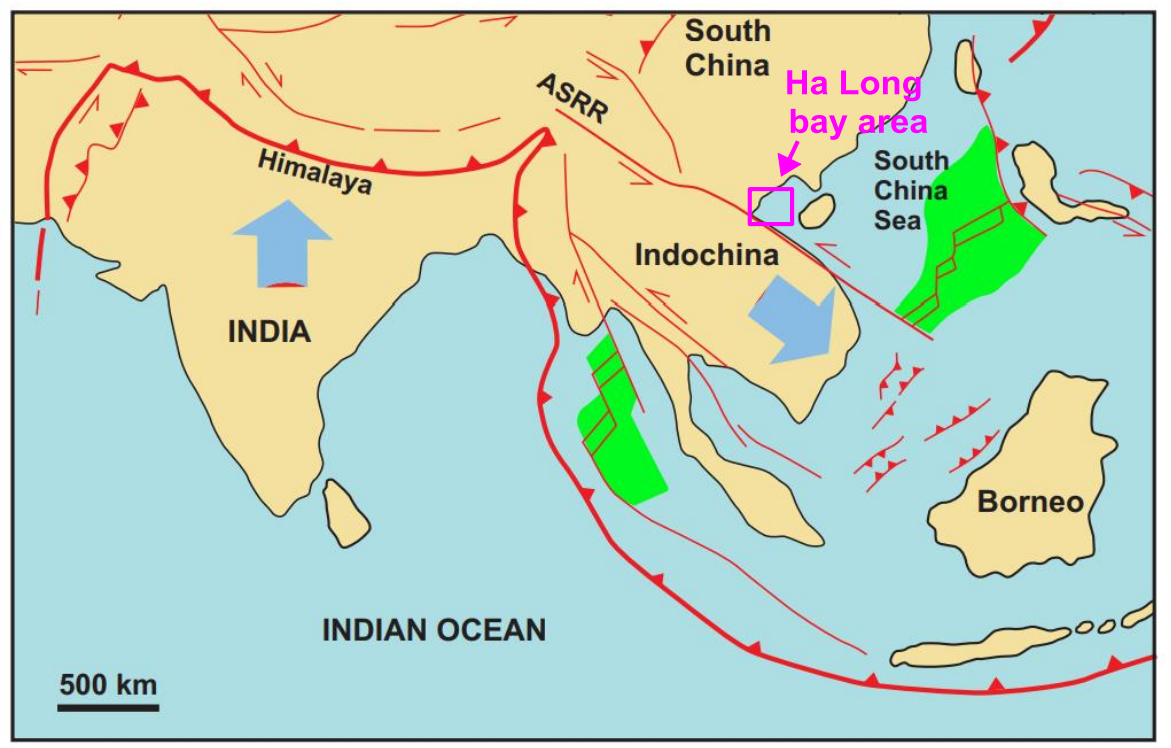

Map (2): Extrusion tectonics and formation of Southeast Asian region (Modified from Tapponnier et al. (1982)).

Due to the impact of regional tectonic activities, the limestone islands in Ha Long bay area were heavily broken, formed fracture systems, developed in the several different directions. Most of the fracture orientations at the survey locations measured have the dip angle vary from 20 to 80 degrees and mainly concentrated within 40 - 60 degrees. The analytical results of rock slope stability according to Hoek and Bray (2004)'s application have determined that most of the fracture orientation obtained and slope direction of limestone islands can form blocks which can occur plane failure.

Besides, the limestone islands in the Ha Long bay have also affected by ocean waves and chemical corrosion (P1.12). 
Analytical results of the stability of some limestone
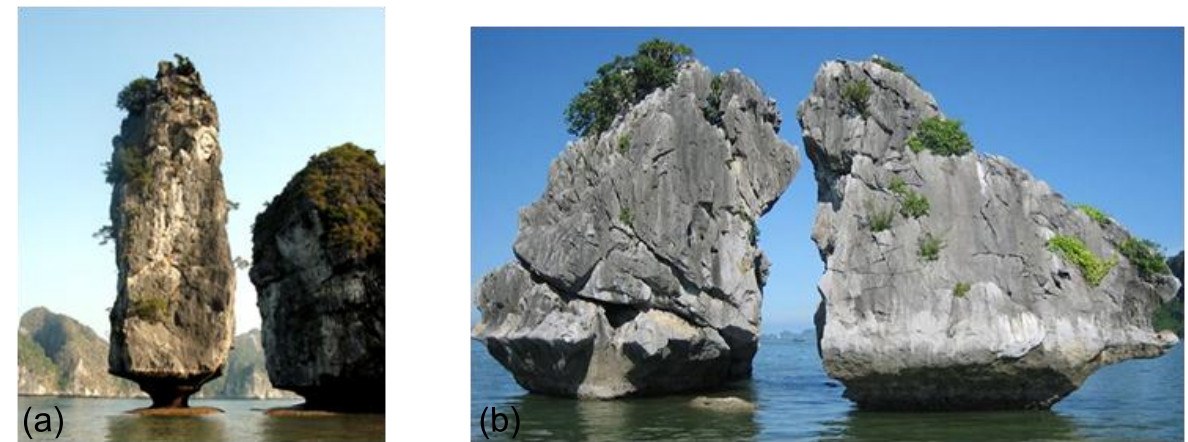

Plate (12): (a) Foot of a stone tower, (b) Ga Choi island is gnawed by ocean waves and chemical corrosion.

The analytical results of this study have important significance for the planning and maintaining the stability of limestone islands in Ha Long bay area.

\section{CONCLUSIONS}

The analytical results of the failure types on 06 limestone islands in the Ha Long bay have identified, all these limestone islands can occur plane failure on the fracture surfaces. The calculated results of safety factor for 03 plane failure blocks lie within 0.9 and 2, have high potential failure. At the same time, the analytical results have also been simulated these islands in three-dimensional space and have been analyzed their potential failure on the fracture surfaces. Especially, the study has been shown the fracture orientation $235^{\circ} / 40^{\circ}$ has cut the head of Thien Nga Island by plane failure. The obtained results as have important significance for planning and development of the Ha Long bay area, a World Natural Heritage, at Quang Ninh province of Vietnam.

\section{ACKNOWLEDGEMENTS}

This paper is supported by the project: "Research, assess the stability of the cave floor system on Ha Long bay to support the management, and promote cave values for tourism development".

\section{LITERATURE CITED}

Anh, L. T. 2015. Analyze the current state of water quality in Ha Long bay, Quang Ninh province, Vietnam", published by IUCN, Gland, Switzerland in collaboration with IUCN Vietnam., "Researching to determine the extremely sensitive marine area of Ha Long - Cat Ba. Vietnam Maritime Administration, Ministry of Transport, 39 pp.

Chinh, V. V. 2002. Neotectonic development phases and mechanism of the Cao Bang-Tien Yen Fault. Vietnam Journal of Earth Sciences, 3 (22): 181-187. (In Vietnamese).

Hoek, E. and Bray, J. 2004. Rock slope engineering, $4^{\text {th }}$ IMM, London, 431 pp.

Lam, D. D. and Boyd, W. E. 2002. Document on the sea level in the middle - late Holocene in Ha Long bay. Journal of Geology, A/270: 1-7. (In Vietnamese). 


\section{Phi Truong Thanh}

Long, H. P. 2012. Tourism impacts and support for tourism development in Ha Long Bay, Vietnam: An examination of residents' perceptions. Asian Social Science, 8 (8): 28-39.

Phach, P. V., Yem, N. T. and Chinh, V. V. 1996. Geodynamic situation in Neotectonic and recent period on Territory of Vietnam. Geology-Resource, National centre for Natural science and Technology institute of Geology, p 101-111. (In Vietnamese).

Rangin, C., Klein, M., Roques, D., Le Pishon, X. and Trong, L. V. 1995. The Red River Fault System in the Tonkin Gulf, Vietnam. Tectonophysics, 243: 209-222.

Tapponnier, P., Peltzer, G. and Armijo, R. 1986. On the mechanics of the collision between India and Asia. In: Coward, M. P., Ries, A. C. (Eds.), Collision Tectonics. Geological Society of London, Special Publication, 19, p 115-157.

Tapponnier, P., Peltzer, G., Le Dain, A. Y., Armijo, R. and Cobbold, P. 1982. Propagating extrusion tectonics in Asia: New insights from simple experiments with plasticine. Geology, 10: 611-616.

Thanh, T. D. 2008. Criteria for evaluating the natural wonders of Ha Long bay. Cultural Heritage Information, 31: 12-15. (In Vietnamese).

Thanh, T. D. 2012. Geological wonders of Ha Long bay. Vietnam Journal of Earth Sciences, 2: 162-172. (In Vietnamese).

Thanh, T. D. and Tony, W. 2001. The outstanding value of geology of Ha Long bay. Advance in Natural Sciences, 2-3: 89-99. (In Vietnamese).

Thanh, P. T., Thinh, P. H. and Ha, N. V. 2018. Rock slope failure blocks and their relation to tectonic activity: A case study in 3B highway, Xuathoa area, Backan province, Vietnam. Bulletin of the Iraq Natural History Museum, 15(2): 207-223.

Thanh, T. D., Tri, T.V., An, L. D., Anh, L. H. and Tony, W. 2004. Ha Long bay, a heritage of geology and geomorphology of the world. Cultural heritage, p 81-84. (In Vietnamese).

Thanh, P. T., Duy, N. T., Thao, N. T. P., Thanh, N. X. and Dat, N. T. 2017. Some results of fracture orientation analysis and its relationship with rockslide on the carbonpermi limestone in Ha Long bay area. International conference on Geo-spatial Technologies and Earth resources, p 521-528.

Van, T. T. 2012. Research in geological processes, modern geodynamics for observation of changes in caves and islands in Ha Long bay. Vietnam Institute of Geosciences and Mineral Resources (VIGMR), 254 pp. (In Vietnamese).

Vu, N. G. 2003. Structural evolution of the block 102 and 106 Song Hong basin-implication for hydrocarbon potential. Proceedings of conference on Vietnam petroleum institute: 25 years of development and achievements, p 284-309. (In Vietnamese). 


\section{Analytical results of the stability of some limestone}

Yem, N. T. 1991. Main features of modern geodynamic in the North Vietnam. GeologyResource, National centre for Natural science and Technology institute of Geology, p7-10. (In Vietnamese). 
Phi Truong Thanh

Bull. Iraq nat. Hist. Mus.

(2019) 15 (4): 455-471

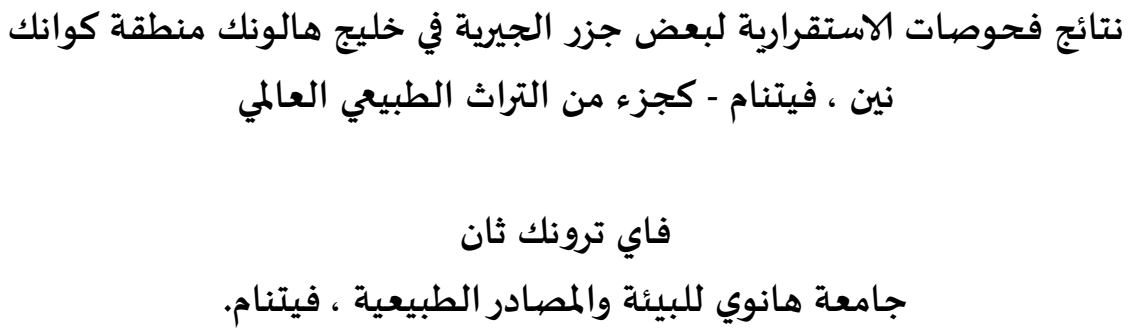

الخلاصة

تم تحديد نتائج الاستقرارية لستة انواع لفحوصات التكسرات لجزر الصخور الجيرية في خليج هالونك منطقة كوانك نين . اظهرت حسابات عامل الامان لمستوى لهات التكسر للبلوك 03 بأنه يقع ضمن نطاق مستوى التكسر العالي بين 2.0-0.9، لقد تم تمثيل النتائج لهذه الجزر في موديل ذو ثلاثة ابعاد وتعين مستوى التكسر الكامن ضمن فئن سطوح التكسر.

لقد اظهرت نتائج البحث اهمية كبيرة في التخطيط لتطوير خليج هالونك كجزء من

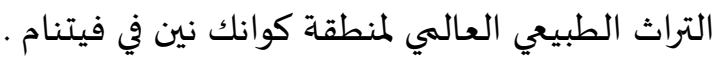

